\title{
Anti-inflammatory Effects and Innate Immunity Suppres sion by Fritillaria ussuriensis Extracts
}

\author{
Jin-Young Seo ${ }^{1}$, Jung-Suk Kim ${ }^{2}$, Kum-Lan $\mathrm{Kim}^{3 *}$ \\ ${ }^{1}$ Department of Cosmetology, Graduate School of Engineering, Konkuk University, Seoul, Korea \\ ${ }^{2}$ Department of Physical Therapy, Hallym Polytechnic University, Chuncheon-si, Gangwon-do, Korea \\ ${ }^{3}$ Gyeonggi Industrial Technical Education Center, Doowon Technical University, Paju-si, Gyeonggi-do, Korea
}

\author{
*Corresponding author: Kum-Lan Kim, \\ Gyeonggi Industrial Technical Education Center, \\ Doowon Technical University, 159 Jurawi-gil, \\ Paju-eup, Paju-si, Gyeonggi-do 10838, Korea \\ Tel.: +82 319357215 \\ Fax: +82319357200 \\ Email: ara320320@naver.com
}

Received May 5, 2017

Revised October 10, 2017

Accepted October 25, 2017

Published March 30, 2018

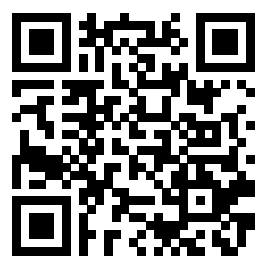

\begin{abstract}
Purpose: The present study aimed to evaluate the anti-inflammatory effects, innate immunity suppression, and cosmetic activity of Fritillaria ussuriensis (FU) extracts in lipopolysaccharide (LPS)-induced inflammatory mice models using serum, blood, and histological analyses. Methods: FU extracts were obtained by refluxing with $80 \%$ ethanol and used to investigate the anti-inflammatory and innate immune responses. Balb/c mice were divided into four groups: a normal group in which acute inflammation was not induced, a control group in which only distilled water was administered, and test groups in which $200 \mathrm{mg} / \mathrm{kg} /$ day and $400 \mathrm{mg} / \mathrm{kg} /$ day of FU extract were orally administered. After the administration, $1 \mathrm{mg} / \mathrm{kg}$ of LPS was injected intraperitoneally in the control and test groups but not the normal group. After $90 \mathrm{~min}$, effects based on cytokine and immune cell analyses and skin histopathological analysis were evaluated. Results: Compared with the control group, the test groups showed reduced serum concentrations of inflammation markers (interferon gamma (IFNy), tumor necrosis factor alpha (TNF $\alpha$ ), interleukin 1 beta (IL1ß), and interleukin 6 (IL6)) and immune markers (white blood cell (WBC) and monocyte markers). The test groups also showed an increased number of granulocytes (neutrophils, eosinophils, and basophils). Moreover, histological examination demonstrated that the FU extract suppressed thickening of the epidermis in the test groups. Conclusion: The results indicate that FU extracts prevented and improved acute inflammation. Thus, FU extracts may be used as raw material for preparing new health foods, medicines, or cosmetics.
\end{abstract}

Keywords: Fritillaria ussuriensis, Immune, Anti-inflammatory, Cosmetics, Cytokine

\section{Introduction}

산업화 및 서구화에 따른 생활환경의 변화뿐만 아니라 환 경오염물질에 대한 노출, 스트레스, 인스턴트 및 포화지방산 이 함유된 식품 섭취 증가 등으로 면역기능이 저하되어 건선, 아토피피부염, 알러지, 천식, 류마티스 관절염 등 다양한 면 역 질환에 대한 관심이 높아지고(quoted in Lee, 2007), 건 강한 아름다움을 추구하는 현대인의 욕구에 의해 화장품 산업 에서 의약품은 아니지만 치료적인 효과를 내는 '코스메슈티컬 (cosmeceutical)' 화장품과 건강기능성 식품 영역까지 포함한 ‘이너뷰티(inner beauty)'라는 영역이 등장하게 되었다(Cho \&
Chung, 2012; Jung et al., 2014b).

면역이란 자극으로부터 인체를 보호하기 위해 외부 이물의 침입이나, 내부의 특이세포 발생 시 면역세포들이 이들을 비자 기(non-self) 항원으로 인식하여 일어나는 생체방어체계를 말 한다(Abo et al., 2005; Choi \& Oh, 2009). 인체 면역계는 크 게 면역을 억제, 조절하는 면역관용(tolerance)과 면역을 증진 하는 면역반응(immunity)으로 구성되어 균형을 이루고 있는 데, 불균형이 일어나 면역관용이 강해지면 암 또는 바이러스 및 세균성 질환을 일으키며, 면역반응이 강해지면 자가 면역 질환, 알러지성 질환과 같은 염증성 질환을 초래한다(Kwon et al., 2008; Lee et al., 2009). 
염증반응은 선천적 면역반응으로 염증 부위에서는 대식세포 (macrophage)가 활성 되어 염증매개물질인 reactive oxygen species (ROS), nitric oxide (NO)와 사이토카인(cytokine) 인 IFN $\gamma, \mathrm{TNF} \alpha$, IL1ß, IL6 등의 발현이 증가되어(Yun et al., 2009) 감염초기의 생체방어에 중요한 역할을 하며 그와 동시에 분비되는 다른 매개물들과 염증반응의 결과로 모세혈관 확장, 발열, 국소적인 부종, 통증, 조직이나 기관의 기능 상실 등이 일어나고 이물질을 제거한 후 조직재생을 통해 종료된다(Byun et al., 2005; Lee et al., 2014).

피부는 생물학적 구조상 방어의 최전선에 위치해 있어 (Sherman \& Hallquist, 1992), 바이러스, 박테리아 또는 화학 항원(chemical antigen)과 만났을 때 면역반응이 일어나, 여드 름(acne vulgaris), 아토피(atopy), 건선(psoriasis), 알레르기 접촉성 피부염(allergic contact dermatitis), 부종(edema) 등 과 같은 염증성 질환의 위험에 노출되고, 과도한 염증반응으로 발생하는 지질과산화는 노화의 진행을 가속화시킨다(Kwon et al., 2012).

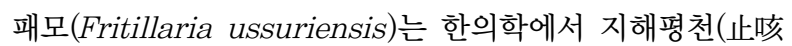
平喘)약으로 기침과 천식을 억제하거나 청화열담(靑火熱痰)약 으로서 악창과 종창과 같은 염증을 제거해주는 외용 처방약으 로서 사용되어 왔으며, 중국에서는 "bei-mu"라는 이름으로 진 해제, 거담제, 항고혈압제, 염증치료, 통증완화제의 주요 약제 로 사용되어 왔다. 패모에는 steroidal alkaloids [saponins, peimine (verticine), perimidine, peiminine (verticinone), imperialine, fritilline, solanidine], adenosine, thymine deoxyriboside, flavonoids 등 항상화, 항염, 함암 등의 약리 효과를 지닌 생물학적 활성 성분을 포함하고 있다(Li et al., 2010; Xu et al., 2016).

면역체계의 붕괴로 일어나는 아토피, 건선, 알레르기 질환 및 각종 피부질환들은 더욱 증가하고 있으나 이를 치료하기 위 해서는 스테로이드제, 항히스타민제 및 면역억제제 외 에는 대 안이 없으며, 국소부위에만 적용가능하고 장기간 사용 시 여러 부작용 사례가 보고되고 있어, 질병의 예방이나 증상 완화 후 관리할 수 있는 기초화장품으로 면역력을 키우며 항염과 항산 화 기능을 갖춘 천연물 소재 개발이 필요하다고 사료된다(Choi et al., 2015). 본 연구에서는 기능적인 식품이나 약제로서의 우수한 효능을 보였으나 화장품 소재로의 사용 가능성에 대한 연구는 미미했던 평패모 추출물의 항염, 선천적 면역반응 억제 실험을 통하여 평패모가 염증질환을 억제하고 피부노화를 예방 하는 기능성 화장품 소재 또는 이너뷰티 소재로서의 가능성에 대한 기초적 자료를 제공하고자 한다.

\section{Methods}

\section{1. 실험동물}

실험동물인 수컷 5 주령의 $\mathrm{Balb} / \mathrm{c}$ 생쥐 $(20-30 \mathrm{~g})$ 는 정상 군, 대조군, 실험군 200,400 그룹별로 각 6 마리, 총 24마리 를 RaonBio (Korea)에서 공급 받아 실험 당일까지 고형사료 (PURINA; Nestl- Purina PetCare, USA)와 물을 충분히 공 급하고 온도 $22 \pm 2{ }^{\circ} \mathrm{C}$, 습도 $55 \pm 15 \%, 12 \mathrm{~h}-12 \mathrm{~h}$ (light-dark cycle)의 환경에서 1 주간 적응시킨 후 실험에 사용하였다. 본 실험은 대전대학교 동물실험윤리위원회의 승인을 받아 동물윤 리준칙에 의거하여 실험하였다(동물실험윤리위원회 승인번호: DJUARB 2016-023).

\section{2. 시약 및 기기}

시약 및 키트는 Dulbecco's Phosphate-Buffered Saline (D-PBS; Welgene, Korea), ethyl ether (Sigma-Aldrich, USA), LPS (Sigma-Aldrich), MILLIPLEX ${ }^{\circledR}$ MAP Mouse Cytokine/Chemokine Magnetic Bead Panel-Immunology Multiplex Assay (Merck Millipore, USA) 등을 사용하였으 며, 사용된 기기는 rotary vacuum evaporator (LABOROTA 20 E R Control; Heidolph Instruments, Germany), $\mathrm{CO}_{2}$ incubator (MCO-18AIC; SANYO Electric, Japan), clean bench (JSCB-1200SB; JSR, Korea), autoclave (JSAC60; JSR), vortex mixer (M37610-33Q; Thermo Fisher Scientific, USA), centrifuge (MF550; Hanil Scientific, Korea), deep-freezer (CLN-700UW; Nihon Freezer, Japan), ice-maker (GB 902; BREMA Ice Makers, Italy), plate shaker (Lab-Line, USA), enzyme-linked immunosorbent assay (ELISA) reader (SpectraMax 190 Microplate Reader; Molecular Devices, USA), Luminex (Luminex SD; Merck Millipore), 환류 추출기(MS-E103; Mtops, Korea), 동결 건조기(FD8512; ILSHINBIOBASE, Korea) 등을 사용하였다.

\section{3. 실험방법}

\section{1) 시료추출}

평패모(Fritillaria ussuriensis, FU) $50 \mathrm{~g}$ 에 $80 \%$ 에탄올 $1 \mathrm{~L}$ 를 넣고 $3 \mathrm{~h}$ 동안 환류 추출 후 여과액을 얻어 rotary vacuum evaporator에서 감압 농축하였다. 농축된 용액을 동결 건조기 로 동결 건조하여 분말 $4.7 \mathrm{~g}$ (수득율 $9.4 \%$ )을 얻었으며, 얻어 진 분말은 deep-freezer $\left(-80^{\circ} \mathrm{C}\right)$ 에서 보관하면서 실험에 따라 필요한 농도로 증류수에 희석하여 사용하였다. 


\section{2) 급성염증유발 및 시료처리}

5 주령의 $\mathrm{Balb} / \mathrm{c}$ 생쥐를 1 주간 안정기를 거친 뒤 6 주령이 된 생쥐를 실험에 사용하였다. 자유식이를 진행하며 급성염증을 유발하지 않는 정상군(이하, Normal)과 증류수만을 투여하는 대조군(이하, Control), FU 추출물을 $200 \mathrm{mg} / \mathrm{kg} /$ day (이하, 200 ), $400 \mathrm{mg} / \mathrm{kg} /$ day (이하, 400)를 투여하는 실험군 총 4개 의 그룹으로 나누어 매일 1회, 오후 2 시에 $200 \mu \mathrm{L}$ 씩 oral zonde (Jeungdo Bio \& Plant, Korea)를 이용하여 7일간 경구 투여하 였다. 7일 후 정상군을 제외한 대조군, 실험군 200, 400에 LPS $1 \mathrm{mg} / \mathrm{kg}$ 을 복강에 주사한 후 $90 \mathrm{~min}$ 후에 ethyl ether로 마취하 고 심장 채혈을 진행하였다. $\mathrm{Balb} / \mathrm{c}$ 생쥐에게 $\mathrm{FU}$ 추출물의 1 회 투여량은 체중 $60 \mathrm{~kg}$ 성인이 1회에 각각 $200 \mathrm{mg} / \mathrm{kg}, 400 \mathrm{mg} /$ $\mathrm{kg}$ 을 섭취했을 때를 기준으로 하여, 성인 1 회 섭취량으로부터 얻 은 시료를 $\mathrm{Balb} / \mathrm{c}$ 생쥐 체중 $30 \mathrm{~g}$ 으로 계산하여 산출하였다. 즉, $\mathrm{Balb} / \mathrm{c}$ 생쥐에게 $\mathrm{FU}$ 추출물의 1회 투여량은 성인 1 회 섭취량 12 $\mathrm{g} / 60 \mathrm{~kg}, 24 \mathrm{~g} / 60 \mathrm{~kg}$ 을 기준으로 하였을 때 $\mathrm{Balb} / \mathrm{c}$ 생쥐 체중 $30 \mathrm{~g}$ 으로 계산한 결과 $6 \mathrm{mg}, 12 \mathrm{mg}$ 을 섭취하도록 하였다.

\section{3) 체중 및 식이섭취량 측정}

6 주령이 된 $\mathrm{Balb} / \mathrm{c}$ 생쥐에게 7일간 시료처리를 하는 기간 동 안의 체중 및 식이섭취량은 매일 오전 10 시에 $\mathrm{g}$ 단위의 저울을 이용하여 측정을 실시하였다.

\section{4) 혈청 내 사이토카인 생성 측정}

혈청 내 사이토카인을 측정하기 위하여 MILLIPLEX ${ }^{\circledR}$ MAP Mouse Cytokine/Chemokine Magnetic Bead PanelImmunology Multiplex Assay를 이용하였다. 동물실험 종료 후 심장 채혈을 통해 얻은 혈액을 $3,000 \mathrm{rpm}$ 조건에서 $20 \mathrm{~min}$ 동안 centrifuge를 돌려 혈청을 분리하였다. 분리한 혈청을 96 well plate에 $25 \mu \mathrm{L}$ 씩 분주하고 assay buffer, matrix solution, antibody-immobilized beads를 각각 $25 \mu \mathrm{L}$ 씩 가하여 혼합한 후 $2 \mathrm{~h}$ 동안 실온에서 반응시키고 washing 완충 용액을 이용하여 2 회 세척하였다. 이후, $25 \mu \mathrm{L}$ 의 detection antibody를 넣은 뒤 $1 \mathrm{~h}$ 동안 plate shaker $(500 \mathrm{rpm})$ 로 반응시키고 추가로 $25 \mu \mathrm{L}$ 의 streptavidin-phycoerythrin을 넣고 다시 plate shaker (500 $\mathrm{rpm}$ )로 반응시킨 뒤 washing 완충 용액을 이용하여 2 회 세척하 였다. 세척 후 D-PBS를 $150 \mu \mathrm{L}$ 넣고 Luminex를 이용하여 IFN $\gamma, \mathrm{TNF} \alpha, \mathrm{IL} 1 \beta, \mathrm{IL} 6$ 를 측정하였다.

\section{5) 혈액 내 면역세포 측정}

혈액 내 면역세포를 측정하기 위하여 동물실험 종료 후 심 장 채혈을 통해 얻은 혈액을 ethylenediaminetetraacetic acid (EDTA) 튜브(Becton, Dickinson and Company, USA)에 담아 Seoul Clinical Laboratories (Korea)에 의뢰하여 백혈구(WBC), 호중구(neutrophil), 호산구(eosinophil), 호염기구(basophil), 단핵구(monocyte), 림프구(lymphocyte) 등의 CBC (complete blood count) 검사를 진행하였다.

\section{6) 조직학적 검사}

등 조직 염색 관찰을 하기 위하여 동물실험 종료 후 등 피부 를 떼어내어 각 실험군 별로 $10 \%$ 중성 포르말린(formalin)에 48 $\mathrm{h}$ 고정하여 Hisko (Korea)에 hematoxylin and eosin (H\&E) 염색을 의뢰하였고 염색된 조직을 광학현미경(Carl Zeiss AG, Germany) 상에서 관찰 및 사진 촬영하였다.

\section{4. 통계처리}

실험 결과는 Statistical Package for the Social Sciences (SPSS) 18.0 (IBM, USA)의 unpaired student's $t$-test 및 analysis of variance (ANOVA)를 사용하여 통계처리 하였으며 $p<0.05, p<0.01$ 및 $p<0.001$ 수준에서 유의성을 검정하였다.

Table 1. Effects of FU extracts on body weight in LPS-induced inflammatory mice models

\begin{tabular}{|c|c|c|c|c|}
\hline \multirow{2}{*}{ Duration } & \multicolumn{4}{|c|}{ Body weight (g) } \\
\hline & Normal & Control & 200 & 400 \\
\hline Initial & $34.8 \pm 1.8$ & $35.2 \pm 1.7$ & $35.0 \pm 2.9$ & $34.4 \pm 1.8$ \\
\hline 1st day & $35.1 \pm 2.0$ & $35.4 \pm 1.7$ & $35.9 \pm 2.6$ & $34.6 \pm 2.0$ \\
\hline 2nd day & $35.3 \pm 2.3$ & $35.5 \pm 2.0$ & $35.5 \pm 2.9$ & $35.0 \pm 1.9$ \\
\hline 3rd day & $35.8 \pm 2.0$ & $36.0 \pm 2.0$ & $35.9 \pm 2.8$ & $35.3 \pm 1.7$ \\
\hline 4th day & $35.8 \pm 2.2$ & $35.9 \pm 2.0$ & $36.3 \pm 2.8$ & $35.4 \pm 1.9$ \\
\hline 5th day & $36.0 \pm 2.3$ & $36.1 \pm 2.1$ & $36.6 \pm 2.7$ & $35.6 \pm 1.9$ \\
\hline 6th day & $36.3 \pm 2.3$ & $36.4 \pm 2.1$ & $36.8 \pm 2.9$ & $36.2 \pm 2.0$ \\
\hline Weight change & +1.5 & +1.2 & +1.7 & +1.8 \\
\hline
\end{tabular}

FU, Fritillaria ussuriensis; LPS, lipopolysaccharide; Normal, untreated Balb/c mice; Control, LPS-induced inflammatory mice models orally administered DW; 200, LPS-induced inflammatory mice models orally administered $200 \mathrm{mg} / \mathrm{kg} /$ day of FU extracts; 400, LPS-induced inflammatory mice models orally administered $400 \mathrm{mg} / \mathrm{kg} /$ day of FU extracts; DW, distilled water. 

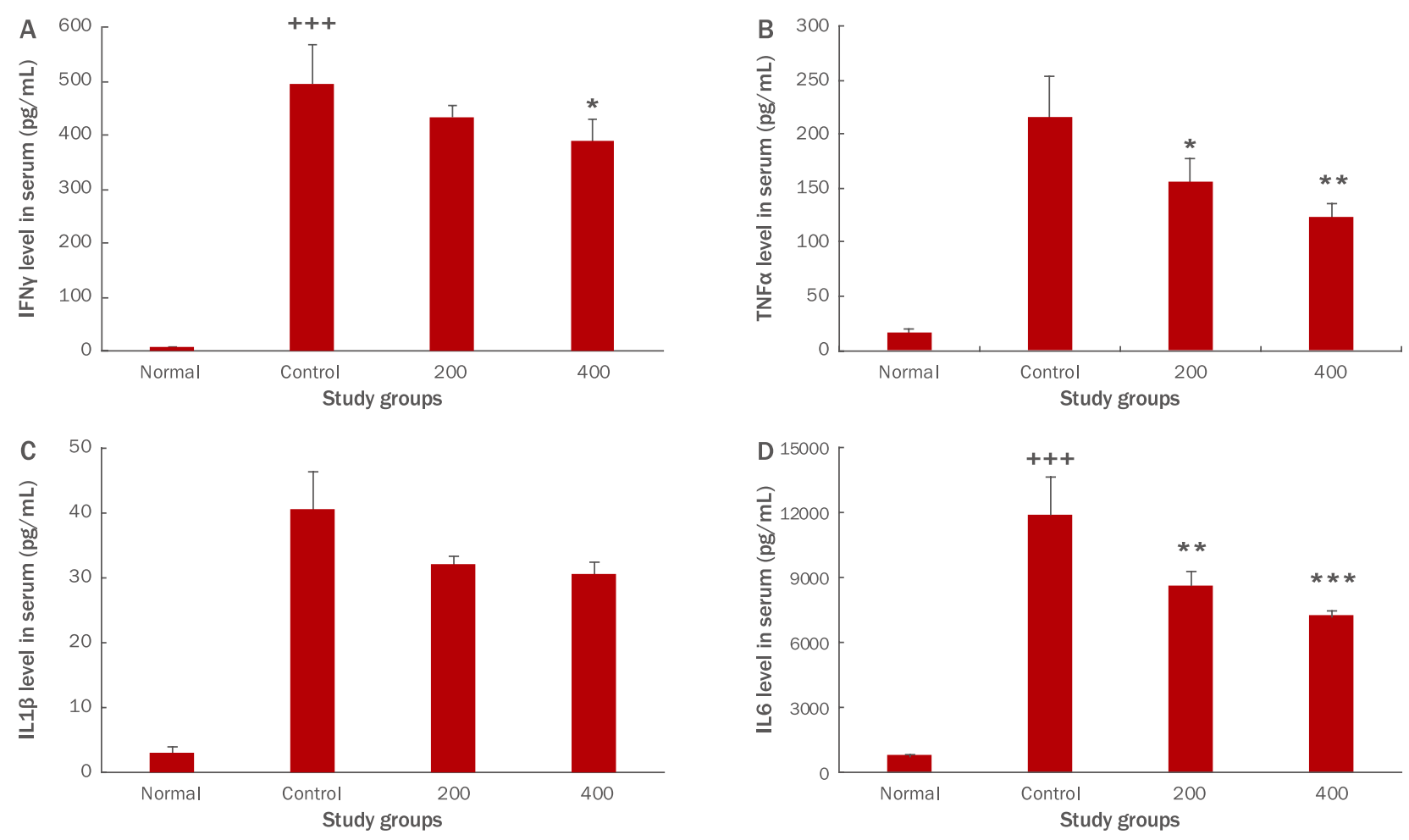

Figure 1. Effects of FU extracts on cytokine levels in serum of Balb/c mice with LPS-induced acute inflammation. Levels of (A) IFNy, (B) TNF $\alpha$, (C) IL1 $\beta$, and (D) IL6. Levels of IFNy, TNF $\alpha$, and IL6 were significantly decreased, whereas those of IL1 $\beta$ were decreased but not significantly. The statistical significance of differences between normal and control groups $\left({ }^{++} p<0.001\right)$ or control and FU extract groups $\left({ }^{* *} p<0.01\right.$; ${ }^{* * *} p<0.001$ ) was determined by ANOVA and the Student's t-test. Results are expressed as M \pm S.D. ( $\mathrm{n}=6$ ). FU, Fritillaria ussuriensis; LPS, lipopolysaccharide; IFNy, interferon gamma; TNF $\alpha$, tumor necrosis factor alpha; IL1 $\beta$, interleukin 1 beta; IL6, interleukin 6; Normal, untreated Balb/c mice; Control, LPS-induced inflammatory mice models orally administered DW; 200, LPSinduced inflammatory mice models orally administered $200 \mathrm{mg} / \mathrm{kg} /$ day of FU extracts; 400, LPS-induced inflammatory mice models orally administered $400 \mathrm{mg} / \mathrm{kg} /$ day of FU extracts; DW, distilled water; ANOVA, analysis of variance; M $\pm S$.D., mean \pm standard deviation.

\section{Results and Discussion}

\section{1. 체중 및 식이섭취량에 미치는 영향}

6주령이 된 Balb/c 생쥐에게 7일간 시료 처리를 하는 기간 동
안 체중 및 식이섭취량을 측정한 결과 체중은 정상군 $+1.5 \mathrm{~g}$, 대 조군 $+1.2 \mathrm{~g}, 200,400$ 투여군 각각 $+1.7,+1.8 \mathrm{~g}$ 의 증가를 보 였다(Table 1). 식이섭취량은 정상군, 대조군, 200 투여군, 400 투여군 각각 $+0.2,+0.5,+0.2,0.0 \mathrm{~g}$ 으로 섭취량이 증가했다

\section{Table 2. Effects of FU extracts on food intake in LPS-induced inflammatory mice models}

\begin{tabular}{lcccc}
\hline \multirow{2}{*}{ Duration } & \multicolumn{3}{c}{ Food intake (g) } \\
\cline { 2 - 5 } 1st day & Normal & Control & 200 & 400 \\
2nd day & 4.8 & 4.6 & 4.8 & 4.9 \\
3rd day & 5.1 & 4.7 & 4.5 & 4.8 \\
4th day & 4.9 & 5.0 & 4.6 & 4.8 \\
5th day & 4.8 & 4.6 & 4.8 & 4.7 \\
6th day & 4.9 & 4.8 & 5.0 & 4.9 \\
Food intake change & 5.0 & 5.1 & +0.2 & 4.9 \\
\hline
\end{tabular}

FU, Fritillaria ussuriensis; LPS, lipopolysaccharide; Normal, untreated Balb/c mice; Control, LPS-induced inflammatory mice models orally administered DW; 200, LPS-induced inflammatory mice models orally administered $200 \mathrm{mg} / \mathrm{kg} / \mathrm{day}$ of FU extracts; 400, LPS-induced inflammatory mice models orally administered $400 \mathrm{mg} / \mathrm{kg} /$ day of FU extracts; DW, distilled water. 


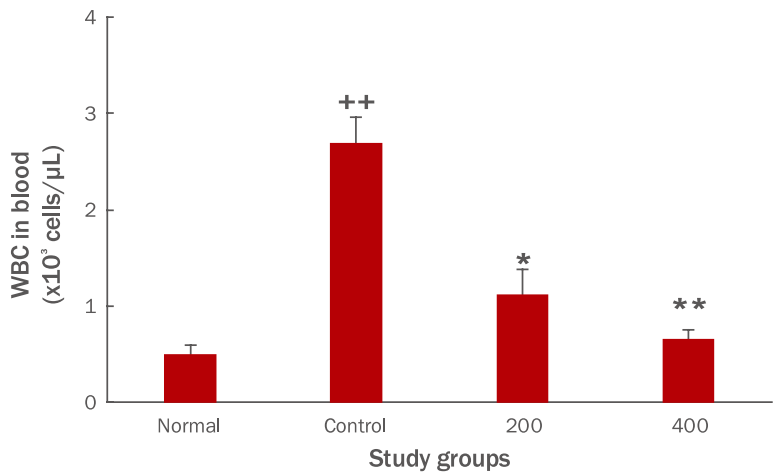

Figure 2. Effects of FU extracts on WBC level in blood of Balb/c mice with LPS-induced acute inflammation.

WBC levels in blood were significantly decreased in the experimental group compared with those in the control group. The statistical significance of differences between the normal and control groups $\left({ }^{++} p<0.01\right)$ or control and FU extract groups ( ${ }^{*} p<0.05$; ${ }^{* *} p<0.01$ ) was determined with ANOVA and the Student's $t$-test. Results are expressed as M \pm S.D. $(\mathrm{n}=6)$. FU, Fritillaria ussuriensis; WBC, white blood cell; LPS, lipopolysaccharide; Normal, untreated Balb/c mice; Control, LPS-induced inflammatory mice models orally administered DW; 200, LPS-induced inflammatory mice models orally administered with $200 \mathrm{mg} / \mathrm{kg} /$ day of FU extracts; 400, LPSinduced inflammatory mice models orally administered with $400 \mathrm{mg} / \mathrm{kg} /$ day of FU extracts; DW, distilled water; ANOVA, analysis of variance; $\mathrm{M} \pm$ S.D., mean \pm standard deviation.

고 볼 수 없기에 위와 같은 결과는 6 주령이 된 $\mathrm{Balb} / \mathrm{c}$ 생쥐의 정상적인 성장으로 보이며 $\mathrm{FU}$ 추출물 섭취가 체중 변화에 영 향을 주지 않는 것으로 판단된다(Table 2).

\section{2. 혈청 내 사이토카인 생성에 미치는 영향}

T helper type 1 (Th1) 세포에 의해 발생하는 Th1 면역반 응(염증성 면역반응)과 $\mathrm{IFN} \gamma$ 에 의해 활성화된 대식세포가 분 비하는 대표적인 염증유발 사이토카인(pro-inflammatory cytokine)으로 TNF $\alpha$, IL1 $\beta$, IL6 등이 있다(Dinarello, 1989; Johnston, 1988; Metlay et al., 1989). 이와 같은 proinflammatory cytokine에 의해 일어나는 염증반응이 가속화 되면 ROS와 reactive nitrogen species (RNS)를 대량 생산 하게 되어 주변 조직에 치명적인 손상을 주고 노화와 함께 알 러지, 자가면역질환 등 각종 질병의 원인이 된다(Jeon et al., 2014).

염증반응으로 인해 과도하게 생성된 IFN $\gamma$ 는 자가염증 이나 건선과 같은 자가면역질환을 유도하고, 대표적 antiinflammatory cytokine인 interleukin 10 (IL10) 생성을 억 제하는 역할을 한다(Jeon et al., 2012). FU 추출물 투여 종 료 후 혈청 내 IFN $\gamma$ 생성량을 측정한 결과, 대조군이 $494.9 \pm$ $72.3 \mathrm{pg} / \mathrm{mL}$ 의 생성을 나타냈을 때, 200 투여군은 $432.8 \pm 21.8$
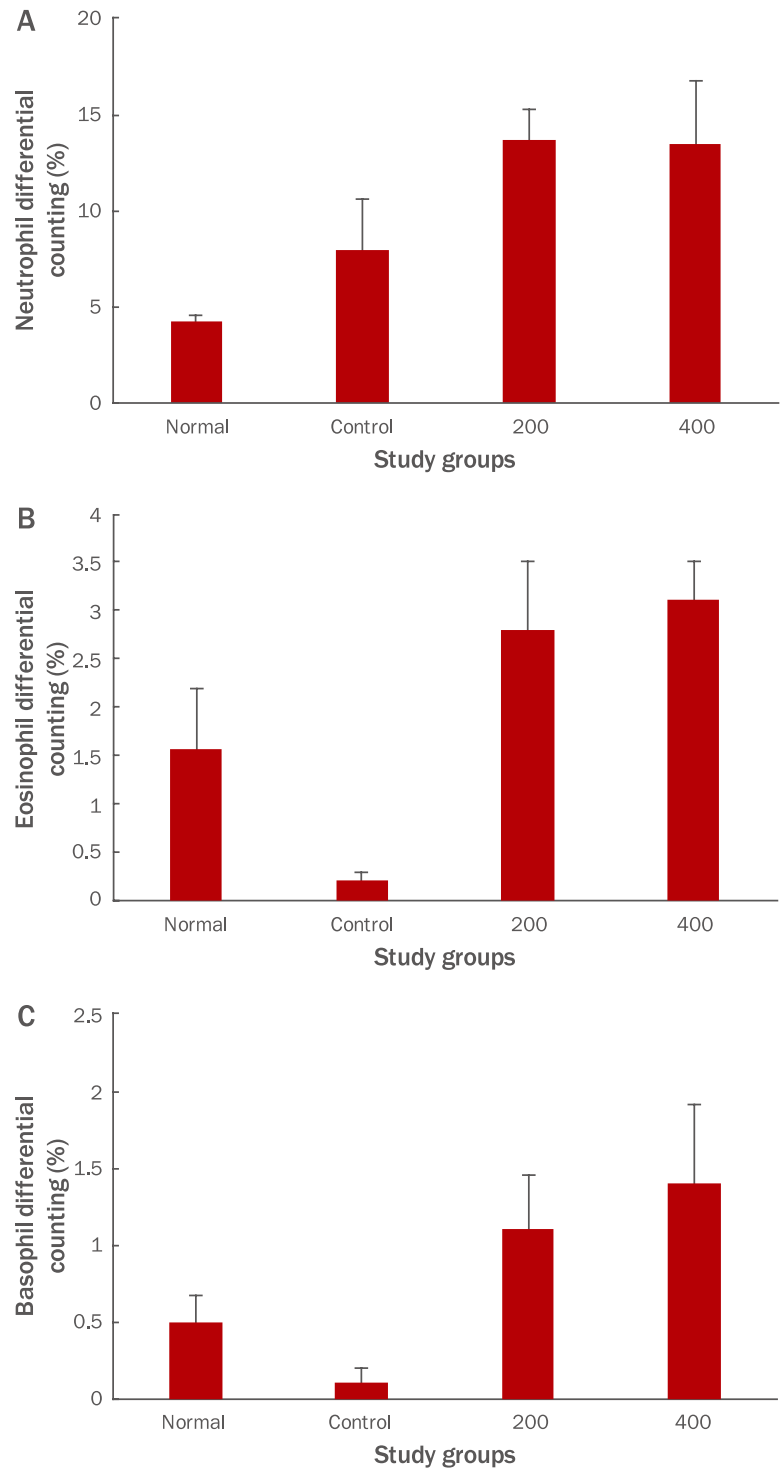

Figure 3. Effects of FU extracts on blood granulocyte levels in Balb/c mice with LPS-induced acute inflammation.

Levels of (A) neutrophils, (B) eosinophils, and (C) basophils. Levels of neutrophils, eosinophils, and basophils were increased but not significantly. Results are expressed as $M \pm S . D$. $(n=6)$. FU, Fritillaria ussuriensis; LPS, lipopolysaccharide; Normal, untreated Balb/c mice; Control, LPS-induced inflammatory mice models orally administered DW; 200, LPS-induced inflammatory mice models orally administered $200 \mathrm{mg} / \mathrm{kg} /$ day of FU extracts; 400, LPS-induced inflammatory mice models orally administered $400 \mathrm{mg} / \mathrm{kg} /$ day of FU extracts; DW, distilled water; $\mathrm{M} \pm$ S.D., mean \pm standard deviation.

$\mathrm{pg} / \mathrm{mL}, 400$ 투여군은 $388.1 \pm 41.6 \mathrm{pg} / \mathrm{mL}$ 로 나타나, $\mathrm{FU}$ 추출물 400 투여군은 대조군에 비하여 유의성 있는 감소를 나타내었 다 $\left({ }^{*} p<0.05\right.$; Figure $\left.1 \mathrm{~A}\right)$.

$\mathrm{Th} 1$ 세포 매개면역과 관련된 $\mathrm{TNF} \alpha$ 를 차단하는 차단제는 대표적인 건선 치료제로 임상에서 효과가 좋다(Jung et al., 


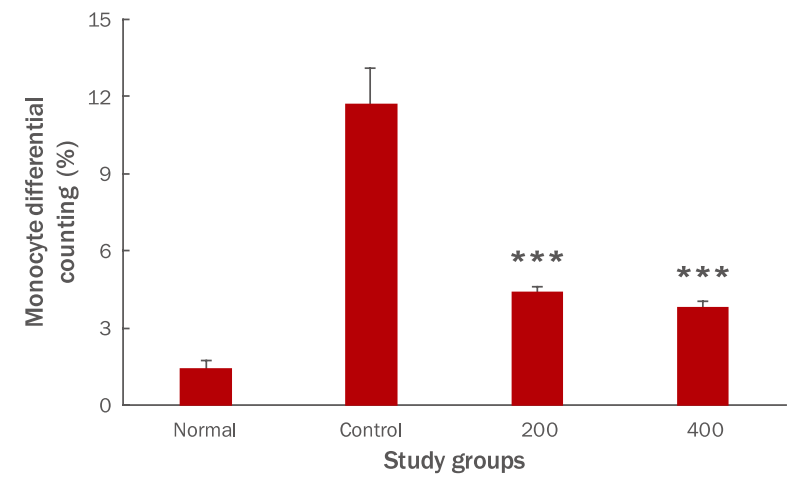

Figure 4. Effects of FU extracts on blood monocyte levels in Balb/c mice with LPS-induced acute inflammation.

Monocyte production was significantly decreased in the experimental group compared with that in the control group $\left.{ }^{* * *} p<0.001\right)$. Results are expressed as $\mathrm{M} \pm \mathrm{SD}(\mathrm{n}=6)$. FU, Fritillaria ussuriensis; LPS, lipopolysaccharide; Normal, untreated Balb/c mice; Control, LPS-induced inflammatory mice models orally administered DW; 200, LPS-induced inflammatory mice models orally administered 200 mg/kg/ day of FU extracts; 400, LPS-induced inflammatory mice models orally administered $400 \mathrm{mg} / \mathrm{kg} /$ day of FU extracts; DW, distilled water; ANOVA, analysis of variance; $M \pm S . D$., mean \pm standard deviation.

2014a). FU 추출물 투여 종료 후 혈청 내 $\mathrm{TNF} \alpha$ 생성량을 측 정한 결과, 대조군이 $216.4 \pm 38.8 \mathrm{pg} / \mathrm{mL}$ 의 생성을 나타냈을 때, 200 투여군은 $156.8 \pm 21.6 \mathrm{pg} / \mathrm{mL}, 400$ 투여군은 123.3 $\pm 14.2 \mathrm{pg} / \mathrm{mL}$ 로 나타나, $\mathrm{FU}$ 추출물 $200,400 \mathrm{mg} / \mathrm{kg}$ 투여군 이 대조군에 비하여 유의성 있는 감소를 나타내었다 ${ }^{*} p<0.05$, ${ }^{* *} p<0.01$; Figure 1B).

IL1 $\beta$ 는 급성 혹은 만성 염증반응의 초기에 관여하여 국소 적 염증반응을 일으키며 호중구와 탐식세포(phagocyte)를 염 증 부위로 이동, 활성화 시켜 제거하는 역할을 한다(Lee et al., 2014). FU 추출물 투여 종료 후 혈청 내 IL1 $\beta$ 생성량을 측정한 결과, 대조군이 $40.5 \pm 5.8 \mathrm{pg} / \mathrm{mL}$ 의 생성을 나타냈을 때, 200 투여군은 $32.1 \pm 1.4 \mathrm{pg} / \mathrm{mL}, 400$ 투여군은 $30.4 \pm 2.2 \mathrm{pg} / \mathrm{mL}$ 로 나타나, 대조군에 비하여 감소하였으나 유의값은 얻지 못하 였다(Figure 1C).

IL6는 염증성 병변에서 수치가 증가하고 림프구를 활성화시 켜 항체 생산을 증가시키는 역할을 하며, 자가면역질환 등의 원인이 된다(Park \& Park, 2007). FU 추출물 투여 종료 후 혈

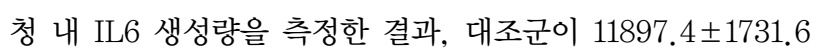

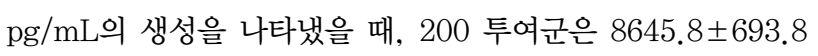
$\mathrm{pg} / \mathrm{mL}, 400$ 투여군은 $7211.9 \pm 289.7 \mathrm{pg} / \mathrm{mL}$ 로 나타나, $\mathrm{FU}$ 추출물 200, 400 투여군이 대조군에 비하여 유의성 있는 감소 를 나타내었다 $\left(^{* *} p<0.01,{ }^{* * *} p<0.001\right.$; Figure 1D).

염증 발생 시 자가염증, 자가면역질환을 일으키고 대표적

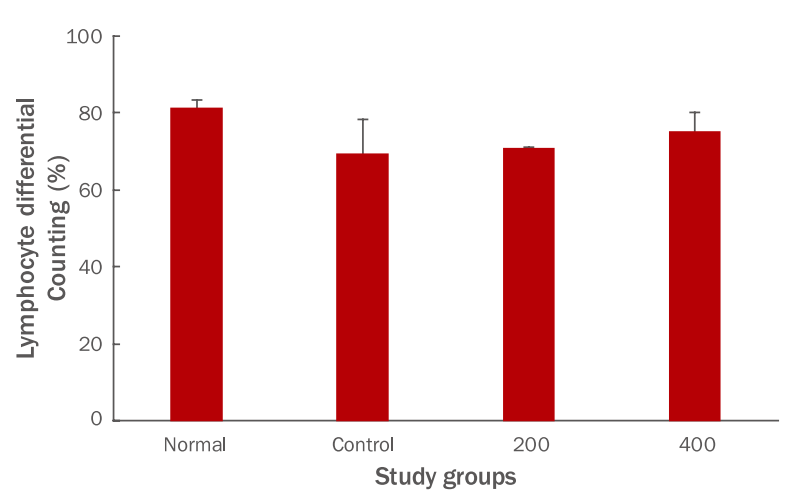

Figure 5. Effects of FU extracts on lymphocyte level in blood of Balb/c mice with LPS-induced acute inflammation. Lymphocyte production did not differ between groups. Results are expressed as $\mathrm{M} \pm \mathrm{SD}(\mathrm{n}=6)$. FU, Fritillaria ussuriensis; LPS, lipopolysaccharide; Normal, untreated Balb/c mice; Control, LPS-induced inflammatory mice models orally administered DW; 200, LPS-induced inflammatory mice models orally administered $200 \mathrm{mg} / \mathrm{kg} /$ day of FU extracts; 400, LPSinduced inflammatory mice models orally administered $400 \mathrm{mg} / \mathrm{kg} /$ day of FU extracts; DW, distilled water; M \pm S.D., mean \pm standard deviation.

anti-inflammatory cytokine인 IL10 생성을 억제하는 것으 로 알려진 $\mathrm{IFN} \gamma$ 는 유의성 있게 감소하는 것으로 보아 $\mathrm{FU}$ 추 출물이 항염증에 효과가 있는 것으로 판단된다. 또한 $\mathrm{IFN \gamma}$ 가 대식세포를 자극하여 생성되는 대표적 pro-inflammatory cytokine인 $\mathrm{TNF} \alpha$ 와 IL6이 유의성 있게 감소하는 것과 $\mathrm{TNF} \alpha$ 와 함께 국소적 염증반응을 만들어 외부 이물질들이 침입한 곳 으로 호중구와 탐식세포를 이동시키는 IL1 $1 \beta$ 의 감소는 종합적으 로 볼 때 $\mathrm{FU}$ 추출물의 항염효과를 뒷받침해주고 있다고 볼 수 있다.

\section{3. 혈액 내 면역세포 생성에 미치는 영향}

혈액 내 면역세포인 백혈구는 탐식작용, 항원제시, 항체생 산, 이상세포 살해 등의 기능을 수행한다. $\mathrm{FU}$ 추출물 투여 종 료 후 혈액 내 백혈구 생성량을 측정한 결과, 대조군이 $2.7 \pm$ $0.3 \times 10^{3}$ 인 cells/ $\mu \mathrm{L}$ 의 생성을 나타냈을 때, 200 투여군은 1.1 $\pm 0.3 \times 10^{3}$ cells $/ \mu \mathrm{L}, 400$ 투여군은 $0.7 \pm 0.1 \times 10^{3}$ cells $/ \mu \mathrm{L}$ 로 나타나, 대조군에 비하여 유의한 감소를 보였다 ${ }^{*} p<0.05$, ${ }^{* *} p<0.01$; Figure 2).

과립구(granulocyte)는 모든 염증반응의 초기대응을 수행하 여 살균, 탐식작용을 하며 급성염증반응의 주역인 호중구, 기 생충을 방어하는 호산구, 염증반응에 관여하는 호염기구로 구 성되어 있다(Yun et al., 2009). FU 추출물 투여 종료 후 호 중구 생성량을 측정한 결과, 대조군이 $7.9 \pm 2.8 \%$ 의 생성을 나 타냈을 때, 200 투여군은 $13.6 \pm 1.7 \%, 400$ 투여군은 $13.4 \pm$ 


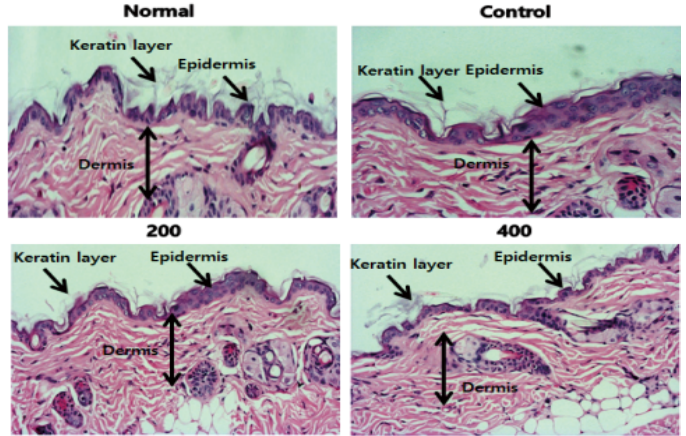

Figure 6. Effects of FU extracts on histopathological examination analysis of Balb/c mice with LPS-induced acute inflammation. Sections were counterstained with H\&E (original magnification, $\times 20$ ). The epidermis of the control group was much thicker than that of the normal group, whereas that of the 200 and 400 groups was thicker than that of the normal group but thinner than that of the control group. Moreover, the thickness of the epidermis in the 400 group was similar to that in the normal group. In addition, there was no significant difference between the keratin layer and dermis thicknesses among the groups. FU, Fritillaria ussuriensis; LPS, lipopolysaccharide; Normal, untreated Balb/c mice; Control, LPS-induced inflammatory mice models orally administered DW; 200 , LPS-induced inflammatory mice models orally administered $200 \mathrm{mg} / \mathrm{kg} /$ day of FU extracts; 400 , LPS-induced inflammatory mice models orally administered 400 $\mathrm{mg} / \mathrm{kg} /$ day of FU extracts; DW, distilled water; H\&E, hematoxylin \& eosin.

$3.4 \%$ 로 나타났다(Figure $3 \mathrm{~A}$ ). 호산구의 경우 대조군이 $0.2 \pm$ $0.1 \%$ 의 생성을 나타냈을 때, 200 투여군은 $2.8 \pm 0.7 \%, 400$ 투여군은 $3.1 \pm 0.4 \%$ 로 나타났으며(Figure $3 \mathrm{~B}$ ), 호염기구는 대 조군이 $0.1 \pm 0.1 \%$ 의 생성을 나타냈을 때, 200 투여군은 $1.1 \pm$ $0.4 \%, 400$ 투여군은 $1.4 \pm 0.5 \%$ 로 나타나(Figure $3 \mathrm{C}$ ), 과립구 모든 그룹에서 대조군에 비하여 증가를 나타내었으나 유의성은 나타나지 않았다.

단핵구는 혈액을 순환하다 조직으로 이동하면 대식세포나 수 지상 세포(dendritic cell)로 분화한다. $\mathrm{FU}$ 추출물 투여 종료 후 단핵구 생성량을 측정한 결과, 대조군이 $11.7 \pm 1.4 \%$ 의 생성을

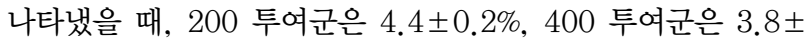
$0.2 \%$ 로 나타나, $\mathrm{FU}$ 추출물 200,400 투여군은 대조군에 비하 여 유의성 있는 감소를 나타내었다 ${ }^{* * *} p<0.001$; Figure 4).

림프구는 염증유발 물질을 제거하고 체액면역을 담당하고 대 식세포의 탐식과 파괴과정을 항진시킨다. $\mathrm{FU}$ 추출물 투여 종 료 후 림프구 생성량을 측정한 결과, 대조군이 $69.6 \pm 8.7 \%$ 의 생성을 나타났을 때, 200 투여군은 $71.0 \pm 0.1 \%, 400$ 투여군 은 $75.3 \pm 4.8 \%$ 로 나타나, 그룹간의 차이가 나타나지 않았다 (Figure 5).
이와 같은 결과는 평패모 추출물이 염증 발생 시 1차적으로 작용하는 과립구를 활성화하여 방어 및 살균작용이 증진되어, 조직으로 이동해 대식세포로 분화 후 염증유발 물질을 제거하 는 단핵구의 생성을 줄여 전체적인 백혈구의 생성량까지 영향 을 준 것으로 해석된다. 단핵구의 감소는 앞선 연구에서 대식 세포에 의해 생성되는 대표적인 염증성 사이토카인인 $\mathrm{TNF} \alpha$, IL6의 유의성 있는 감소와 IL $1 \beta$ 의 수치감소 결과와 부합되어 평패모의 면역증진효과를 더욱 뒷받침하고 있다. 다만, 과립구 중 기생충 방어와 염증반응에 관여하는 호산구와 호염기구의 수치가 대조군에서 감소, 실험군에서 증가한 결과와 림프구 수 의 정상군, 대조군, 실험군 모두 변화 없음은 $\mathrm{T}$ helper type 2 (Th2) 세포에 의해 특이적으로 발현되는 사이토카인 및 면역과 관련된 유전자 확인 등의 심도 있는 연구가 추후 지속적으로 이 루어져야 할 것으로 판단된다.

\section{4. 조직학적 검사}

실험 종료 후 등 조직을 적출하여 $\mathrm{H \& E}$ 염색을 통해 각질층 (keratin layer), 표피층(epidermis), 진피층(dermis)을 확인한 결과, 대조군은 정상군에 비해 표피층이 두꺼워진 것을 확인할 수 있었다. 반면, 평패모 200,400 투여군은 정상군에 비해 표 피층의 두께가 두꺼워졌지만 대조군에 비해 두께가 얇았고 고 농도 투여군일수록 정상군과 비슷한 두께를 나타내었으며, 각 질층과 진피층은 정상군, 대조군, 실험군 모두 큰 차이가 나타 나지 않았다(Figure 6). FU 추출물 투여가 손상에 대한 즉각적 인 반응으로 발생하는 염증으로 인한 부종으로 표피조직이 두 꺼워 지는 것을 예방할 수 있다고 해석된다.

\section{Conclusion}

평패모(FU) 추출물의 항염효과와 선천면역반응 억제효과를 객관적으로 검증하기 위하여 다양한 연구를 진행한 결과 다음 과 같은 결론을 얻었다.

첫째, $\mathrm{FU}$ 추출물 투여군은 혈청 내 사이토카인 생성 측정결 과, 대조군에 비하여 IFN $\gamma, \mathrm{TNF} \alpha$, IL6 생성량을 유의성 있게 감소시켰으며 IL1 생성량은 감소시켰으나 유의성이 나타나지 않았다(Figure 1).

둘째, $\mathrm{FU}$ 추출물 투여군은 혈액 내 면역세포 생성 측정결 과, 대조군에 비하여 백혈구 생성량을 유의성 있게 감소시켰다 (Figure 2). 호중구, 호산구 및 호염기구 생성량은 증가시켰으 나 유의성이 나타나지 않았고(Figure 3), 단핵구 생성량은 유 의성 있게 감소하였다(Figure 4). 림프구 생성량은 그룹간의 차이가 나타나지 않았다(Figure 5).

셋째, $\mathrm{FU}$ 추출물 투여군은 대조군에 비하여 표피층의 두께 
가 얇았으며, 고농도 투여군일수록 정상군과 비슷한 두께를 나타내었으며 각질층과 진피층은 큰 차이가 나타나지 않았다 (Figure 6).

이와 같은 결과를 통해 평패모 추출물은 면역 개선과 항염에 효능이 있음을 확인하였으며, 향후 다양한 식 · 의약품, 화장품 소재로 활용될 수 있음을 시사하고 있다.

This work is part of the Jin-Young Seo's M.S. thesis at the Konkuk University, Seoul, Korea.

\section{References}

Abo T, Kawamura T, Watanabe H. Immunologic states of autoimmune diseases. Immunologic Research, 33: 2334, 2005.

Byun SH, Yang CH, Kim SC. Inhibitory effect of Scrophulariae Radix extract on TNF- $\alpha$, IL-1 $1 \beta$, IL- 6 and nitric oxide production in lipopolysaccharide-activated Raw 264.7 cells. The Korea Journal of Herbology, 20: 7-16, 2005.

Cho YK, Chung JY. The inner beauty of the beauty market in Korea and preference investigation. Journal of Korea Design Forum, 36: 365-378, 2012.

Choi EJ, Kin EK, Ji YS, Lee CJ. Inhibitory effect of mushrooms extract on TNF- $\alpha /$ INF- $\gamma$ induced-cytokine in human keratinocytes, HaCaT. Journal of Mushrooms, 13: 170$174,2015$.

Choi JH, Oh DH. Effect of white and red ginseng extracts on the immunological activities in lymphocytes isolated from sasang constitution blood cells. Journal of Ginseng Research, 33: 33-39, 2009.

Dinarello CA. Interleukin-1 and its biologically related cytokines. Advances in Immunology, 44: 153-205, 1989. Jeon IH, Kang HJ, Kim SJ, Jeong SI, Lee HS, Jang SI. Antioxidant and antipruritic activities of ethyl acetate fraction from Diospyros lotus leaves. Journal of the Korean Society of Food Science and Nutrition, 43: 1635-1641, 2014.

Jeon YJ, Yoo H, Kim BH, Lee YS, Jeon B, Kim SS, Kim TY. IFNy-mediated inhibition of cell proliferation through increased PKCס-induced overexpression of EC-SOD. BMB Reports, 45: 659-664, 2012.

Johnston RB. Current concepts: immunology. Monocytes and macrophages. The New England Journal of Medicine, 318: 747-752, 1988.
Jung HJ, Kim KH, Yoon Jl, Park MY, Ahn JY. A case of atopic dermatitis with psoriasis. Korean Journal of Dermatology, 52: 417-420, 2014b.

Jung HK, Kim KS, Jeong YS. Wound healing effects of Lespedeza cuneata extract. Journal of the Korean Society of Food Science and Nutrition, 43: 374-380, 2014a.

Kwon HG, Hwang JS, So JS, Im SH. Immunological homeostasis and inflammatory immune disorders. Molecular and Cellular Biology Newsletter, 20: 48-69, 2008.

Kwon MJ, Kim B, Lee YS, Kim TY. Role of superoxide dismutase 3 in skin inflammation. Journal of Dermatological Science, 67: 81-87, 2012.

Lee EC. Health behavior theory. Yasmedia Publishing House, Seoul, p18, 2007. (Matsumoto C. 2002.)

Lee HY, Kim KL, Yun MY, Kang SM. The effect of essential oil mixture in a mouse model of allergic asthma. Asian Journal of Beauty and Cosmetology, 7: 117-131. 2009.

Lee YJ, Sim BY, Lee HJ, Bak JW, Kim DH. Effect of GamiChunggisan on antioxidant and pro-inflammatory cytokine. The Korea Journal of Herbology, 29: 69-76, 2014.

Li X, Gao WY, Huang LJ, Wang YL, Huang LQ, Liu CX. Preparation and physicochemical properties of carboxymethyl Fritillaria ussuriensis Maxim. starches. Carbohydrate Polymers, 80: 768-773, 2010.

Metlay JP, Puré E, Steinman RM. Control of the immune response at the level of antigen-presenting cells: $a$ comparison of the function of dendritic cells and $B$ lymphocytes. Advances in Immunology, 47: 45-116, 1989.

Park YL, Park J. Pathogenesis of atopic dermatitis. Korean Journal of Investigative Dermatology, 14: 67-72, 2007.

Sherman AR, Hallquist NA. Immunity. Journal of Nutrition and Health, 25: 287-306, 1992.

Xu J, Zhao W, Pan L, Zhang A, Chen Q, Xu K, Lu H, Chen Y. Peimine, a main active ingredient of Fritillaria, exhibits anti-inflammatory and pain suppression properties at the cellular level. Fitoterapia, 111: 1-6, 2016.

Yun MY, Bang MC, Chin CH, Cheong KJ. The effect of antioxidative and anti-inflammatory functional in Sandalwood oil. Asian Journal of Beauty and Cosmetology, 7: 263273, 2009. 


\section{국문초록}

\section{평패모 추출물의 항염효과와 선천 면역반응 억제}

서진영 ${ }^{1}$, 김정숙 ${ }^{2}$, 김금란 ${ }^{3 *}$

${ }^{1}$ 건국대학교 산업대학원 향장학과, 서울, 한국

${ }^{2}$ 한림성심대학교 물리치료과, 강원도 춘천시, 한국

${ }^{3}$ 두원공과대학교 경기산업기술교육센터, 경기도 파주시, 한국

목적: 본 연구는 혈청, 혈액 및 조직학적 분석을 이용하여 lipopolysaccharide (LPS)로 급성염증이 유도된 마우스 모델에서 항염증, 선천적 면역반응 억제 및 미용작용에 대한 평패모 추출물의 능력을 평가하고자 하였다. 방법: 평패모 추출물의 항염 및 선천면역반 응 억제 효과를 확인하기 위하여, $80 \%$ 에탄올로 환류추출하여 평패모 추출물을 얻었다. Balb/c 생쥐를 급성염증을 유발하지 않는 정상군과 증류수만을 투여하는 대조군, 평패모 추출물을 $200 \mathrm{mg} / \mathrm{kg} / \mathrm{day}, 400 \mathrm{mg} / \mathrm{kg} / \mathrm{day}$ 를 투여하는 실험군 총 4 개의 그룹으로 나누어 7일간 경구 투여한 후, 정상군을 제외한 대조군, 실험군 200, 400에 LPS $1 \mathrm{mg} / \mathrm{kg}$ 를 복강에 주사하였다. $90 \mathrm{~min}$ 후, 사이토 카인과 면역세포 분석 및 등 피부 조직 병리학적 분석에 근거한 효과를 평가했다. 결과: 대조군과 비교하여 평패모 추출물 투여군 은 염증 표지자(interferon gamma ( $(F N \gamma)$, tumor necrosis factor alpha ( $\mathrm{TNF} \alpha$ ), interleukin 1 beta (IL1ß), 및 interleukin 6 (IL6)), 면역 마커(백혈구 및 단핵구)의 생성량을 감소시킨 반면, 과립구(호중구, 호산구 및 호염기구)의 농도를 증가시켰다. 또한, 조직검사 결과, 평패모 추출물은 표피의 증식을 억제하는 것으로 나타났다. 결론: 평패모 추출물의 급성염증 예방 및 개선효과를 통해 평패 모 추출물의 새로운 건강식품, 의약품 또는 화장품 원료로서의 개발가능성을 확인할 수 있었다.

핵심어: 평패모, 면역, 항염, 화장품, 사이토카인

\section{참고문헌}

권호근, 황지선, 소재선, 임신혁. 면역학적 항상성과 염증성 면역질환. 분자세포생물학 뉴스레터, 20: 48-69, 2008. 박영립, 박 준. 아토피피부염의 병인. 대한피부연구학회지, 14: 67-72, 2007.

변성희, 양재하, 김상찬. 현삼메탄올 추출물이 LPS로 유도된 Raw 264.7 cell에서의 TNF- $\alpha, \mathbb{L}-1 \beta, \mathrm{L}-6$ 및 nitric oxide 생성에 미치는 영향. 대한본초학회지, 20: 7-16, 2005.

윤미영, 방민정, 진정화, 정광조. 샌달우드 오일의 항산화 및 항염증에 관한 효과. 아시안뷰티화장품학술지, $7: 263-273,2009$. 이윤정, 심부용, 이해진, 박지원, 김동희. 加味清肌散(가미청기산)이 항산화와 염증성 사이토카인에 미치는 영향. 대한본초학회 지, 29: 69-76, 2014.

이응철. (보건의료 및 자연치유(보완대체의학) 종사자를 위한) 건강행동이론의 입문: 생활습관병을 중심으로. 야스미디어, 서울, p18, 2007. (마츠모토 치아키. 2002)

이혜연, 김금란, 윤미영, 강상모. 에센셜 오일 혼합물이 알레르기성 천식 생쥐 모델에 미치는 효과. 아시안뷰티화장품학술지, $7:$ 117-131, 2009.

전인화, 강현주, 김상준, 정승일, 이현서, 장선일. 고욤(Diospyros lotus)잎 유래 Ethyl Acetate 분획물의 항산화 및 항가려움 활

성. 한국식품영양과학회지, 43: 1635-1641, 2014.

정혜정, 김경호, 윤재일, 박미연, 안지영. 건선을 동반한 아토피 피부염. 대한피부과학회지, 52: 417-420, 2014.

정희경, 김길수, 정유석. 야관문 추출물의 창상치유 효과. 한국식품영양과학회지, 43: 374-380, 2014.

조유경, 정재윤. 국내 뷰티시장의 이너뷰티 현황 및 선호도조사. 한국디자인포럼, 36: 365-378, 2012.

최은주, 김은경, 지용석, 이창진. 버섯류 추출물의 피부각질세포(HaCaT cell) 내 염증성 사이토카인 억제효과. 한국버섯학회지, 13: 170-174, 2015. 


\section{中文摘要}

\section{平贝母提取物的抗炎作用和先天免疫抑制作用}

徐瑱英 ${ }^{1}$, 金貞淑 $^{2}$, 金金蘭 $^{*}$

${ }^{1}$ 建国大学产业大学院香妆学科, 首尔, 韩国

2翰林圣心大学物理治疗科, 江原道春川市, 韩国

${ }^{3}$ 斗源工科大学京畿产业技术教育中心，京畿道坡州市，韩国

目的: 在lipopolysaccharide (LPS)诱导急性炎症的小鼠模型中, 利用血清, 血液和组织学分析方法, 评价平贝母提取物 的抗炎, 先天免疫抑制以及美容作用。方法: 为确认平贝母提取物的抗炎, 先天免疫抑制作用, 利用 $80 \%$ 乙醇环流提取 平贝母提取物。将Balb/c小鼠分为四组：未诱发急性炎症的正常组，仅施用蒸馏水的对照组，每天口服平贝母提取物 $200 \mathrm{mg} / \mathrm{kg}, 400 \mathrm{mg} / \mathrm{kg}$ 的实验组。经过7天口服给药后, 除了正常组, 在对照组和实验组腹腔注射 LPS $1 \mathrm{mg} / \mathrm{kg}$ 。经过 $90 \mathrm{~min}$ 后, 基于细胞因子和免疫细胞分析以及皮肤组织病理学分析, 评估平贝母提取物的功效。结果: 与对照组相比, 实验组减少了炎症标志物 (interferon gamma (IFN)), tumor necrosis factor alpha (TNFa), interleukin 1 beta (IL1ß) 以及 interleukin 6 (IL6))和免疫标志物 (白血球和单核细胞) 的生成量。实验组还显示增加了粒细胞 (嗜中性粒细胞, 嗜酸性粒细 胞和嗜碱性粒细胞) 的浓度。此外, 组织学检查表明平贝母提取物抑制了实验组表皮的增厚。结论: 平贝母提取物能够预 防和改善急性炎症。因此，平贝母提取物可以用作制备新的健康食品，药物或化妆品原料。

关键词: 平贝母, 免疫, 抗炎, 化妆品, 细胞因子 